$<$ 应例報告 $>$

\begin{tabular}{|c|c|c|c|c|c|c|}
\hline 竹林 & 治朗* & 神野 & 健二 & 佐々木伸彌 & 山田 & 信 \\
\hline 且 & 明良 & 山本 & 春美** & 岩原 定可*** & 平川 & \\
\hline 平田 & 和文 & 島明 & 宜浩 & 長島 秀夫**** & & \\
\hline
\end{tabular}

要 旨 : 長期間にわたる多量の常飲者で，過飲による増悪と，断酒による軽快を絽り返した 2 症 例につき，2 年以上経過を追跡して，経時的に腹腔鏡検查と肝生検を繰り返し検索した。アルコ 一ル性肝炎では，その繰り返しにより約 2 年間で壊死後性肝硬変が 完成され，門脈性肝硬変で は,アルコール性肝炎が繰り返されると約 1 年間で塤死後性肝硬変へと進展した．これらの観察 から，アルコール性肝硬变の進展にはアルコール性肝炎が重大な影響を及添していることが明ら かにされた。

索引用語：アルコール性肝炎フルコール性肝硬変＼cjkstart常飲者

はじめに

アルコール性肝硬変の進展には，その経過中にみられ るアルコール性肝炎が重要な役割を果していると考党ら れている゙.アルコール性肝炎の予後観察では，断酒後 3〜6月間で回復する例と，しない例があり，後者では 断酒を続けたとしても，领酒を続けた例と同様にフルコ 一ル性肝炎が持続するか，あるいは次第に䀒硬変へ移行 する ${ }^{1,2)}$. 最近, アルコール性肝硬変の進展には，アル コールや栄責因子のほが”，免疫学的機序の関与を考 検討を加えられた文献がある゙。

我々は，長期間にわたる大量の常领者で，過领後につ ルュール性肝炎が起り，断酒により軽快し，この增悪と 軽快をたびたび繰り返して，肝硬変へ進展した過程を肝 組織像の面から経時的に観察しえた 2 症例を経験したの で，この 2 症例を中心にアルコール性肝炎がフルコール 性肝硬変進展に及ぼす影響につき洘察を加え報告する。

店例 1 浅O剛，43葴，男子, 大工.

主訴：黄庭。

既往歷：16歳で虫垂切除術を受けた。

*国立岩国病院消化器科医辰（琴 高松赤十字病 院消化器科部長）

**同内科

****同院長

***** 网山大学医学部第一内科

<受付日52年 3 月11日 $>$
家族歴：父親む酒豪で常飲しているが著患を知らな W.

领酒歴：昭和25年頃より飲酒を始め，次第に連日领酒 し， 昭和 40 年頃 上り清酒概算一日量 $900 \mathrm{~m} l$ を連日飲酒 し，時には $1,800 \mathrm{~m} l$ K及んで過领する事があり，副食及 び主食を汪とんど摄取しなかった。

現病歴：昭和44年 8 月頃より過领が綕くと，全身隐莣 感, 脱力, 食欲不振, 悪心が出現したが，そのまま仕事 していた，愁訴が增強したため，同11月19日より䄪 3 週 間入院加療を受け愁訴は消失した，その時始めて肋弓下 約 3 横指径の肝腫大を指摘された. 退院後再び清酒概算 一日量 $900 \mathrm{~m} l$ を連日飲酒しながら普通に大工仕事をして いた.

昭和 47 年 3 月中旬上り全身倦急感，食欲不振が強くな り, 同 6 月 12 日上り約 3 週間入院加療を受け，愁訴は消 失した。 入院期間中は断酒していたが，退院後はすぐ领 酒を始めた。

昭和48年 5 月頃過领が続いたのち，全身倦宫感，食欲 不振，右季助部痛が出現して，次第に增悪し，同 8 月11 日より10月22日まで入院加療を受け，愁訴は消失した。 同10月12日第 1 回目肝盲生検を施行した。退院後にまた 领酒を続けていたら愁訴が出現したが仕事していた。

昭和49年 6 月初旬より悪心，食欲不振，倦意感が增強 し，同6月20日より9月19日まで入院加療を受け，愁訴 は消失した，同 7 月29日に第 1 回目腹势鏡扣よび第 2 回 
目肝生検を施行した。その後，再び清酒概算一日量720 $\mathrm{m} l$ を领酒しながら就学していた。

昭和50年 6 月 10 日頃より清酒概算一日量 $1,800 \mathrm{~m} l$ を 4 日間飲み続け，副食を汪とんど搷取しなかったところ， 急速に食欲不振が増強し, 悪心, 呕吐, 倦急感, 寝汗, 手指振戦枕よび黄㡺が出現した. 食欲不振と呕吐のため 食事撕取が出来ず，清酒と水分のみ领んでいたが，水分 摄取も不能となり，同6月19日入院した．入院後，断 酒し, 点滴加療により愁訴は消失し, 同 9 月 12 日退院し た. 同 8 月30日第 3 回目の肝盲生検を施行 した。退院 後, 少量より领酒を始め, 次第に量は多くなったが仕事 はしていた。

昭和50年12月中旬上り食欲不振，悪心，呕吐，倦怠感 あり，同12月20日より黄序が出現し，同12月23日より食 事はとれず，水分摂取む十分出来なくなり，るいそらし て同12月25日入院した，入院後は断酒し，点滴加療に上 り,愁訴は消失し, 昭和51年 4 月 5 日退院した。同 1 月 12日第 2 回目腹盐鏡お゙よ゙第 4 回肝生検を施行した．退
院後，2週間は断酒していたが，また领酒を始めたるの の以前殅ど拎めなくなった，清酒概算一日量 $540 \mathrm{~m} l$ 連 日领酒している。

昭和51年 4 月 22 日に黄疸に気つきき, 食欲不振，悪心， 腹満, 倊急感が增強し, 同 5 月22日に吐血して緊急入院 した。

現应：（昭和51年 5 月22日）体格中等，栄荃不良，皮 洁は㛺燥し，黄㡺色で，星芒状毛細血管怒張著明，手掌 紅斑軽度，手指振戦著明で，白爪であった。咽頭粘膜は 発赤していた．脈拍は顅で，整，血王 $140 / 70 \mathrm{mmHg} て ゙$ あった. 眼球結膜黄病著明で, 眼眕結膜充血していた. 心缄・肺に異常なかった．肺肝境界第 6 肋間. 腹部は膨 満し，鼓腸と腹永があった。肝葴は肋弓下に約 5 横指径 触知し，辺縁鈍で，表面不整，硬度は硬く，压痛があっ た、脾蔵は触知しなかった。㮏蓋・アキレス腱反射は両 側ともやや元進していたが，病的反射はなかった．浮腫 むなかった。

入院時検查成楼：（昭和51年 5 月）(Table 1) 白血球

Table 1. Case 1 Laboratory findings on admission

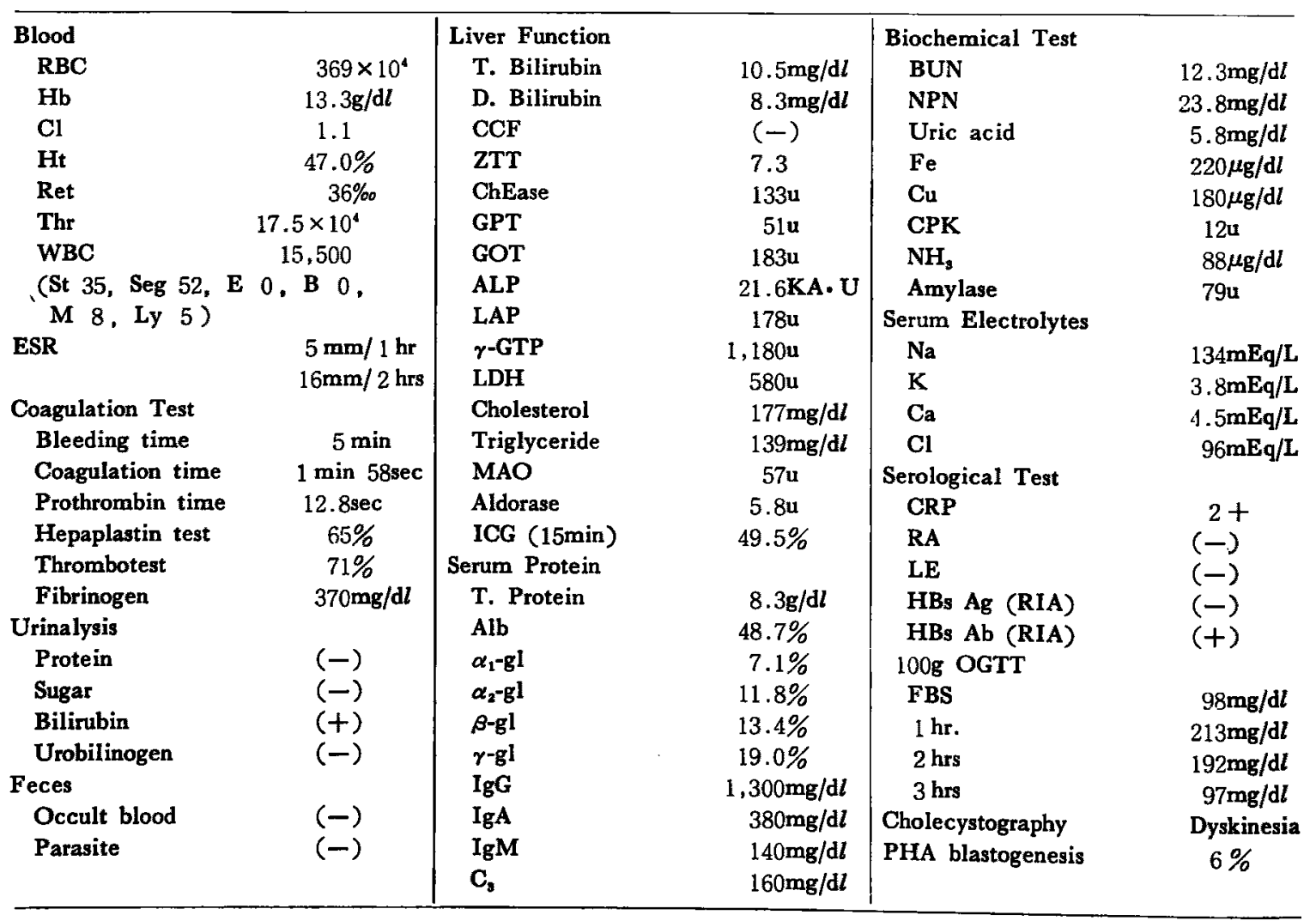


Case 1 T. ASANO male $47 \mathrm{yrs}$.

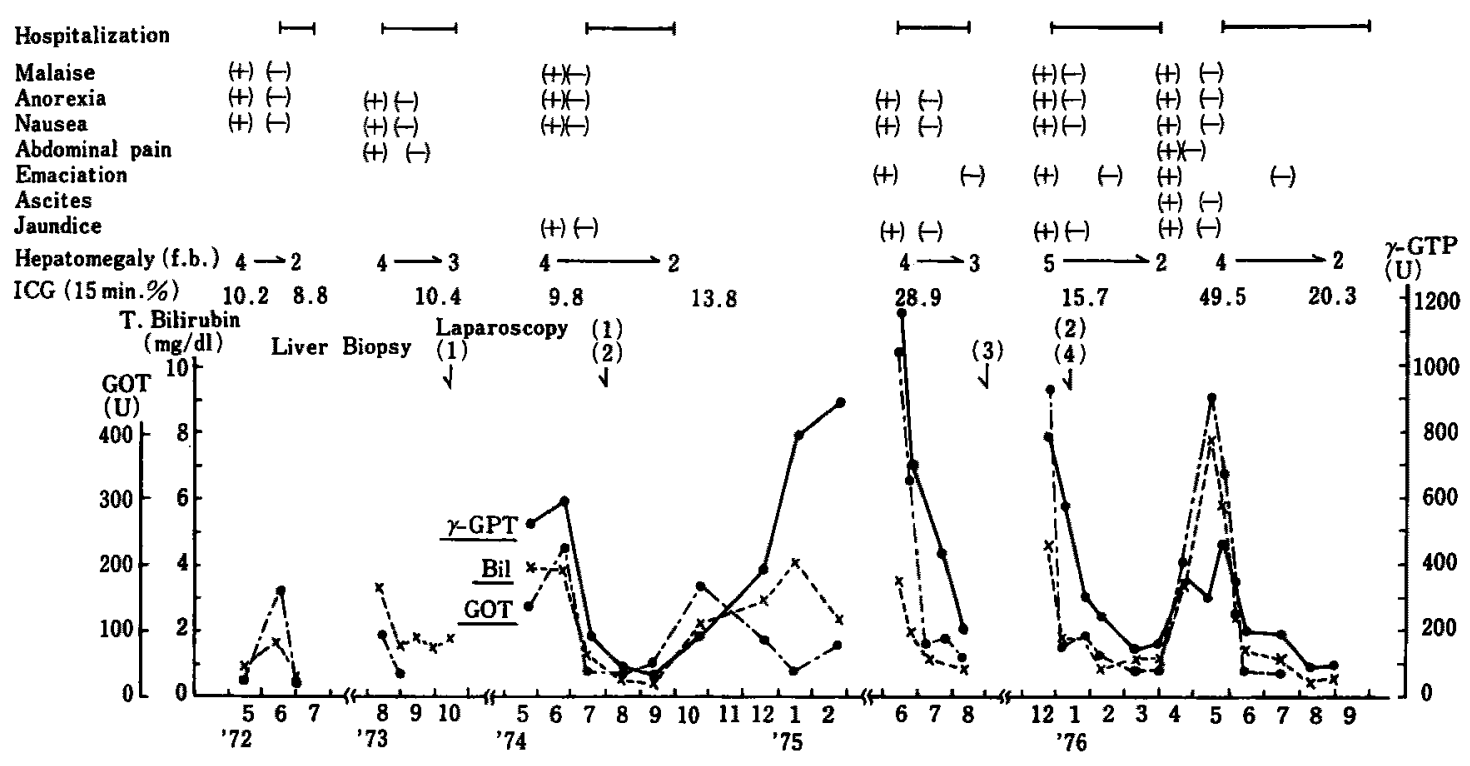

Fig. 1 Clinical course

增多, 血清ビリルビン上昇, 血清トランスアミナーゼ上 昇 (GOT $>$ GPT), ALP 上昇, $\gamma$-GTP 上昇, MAO 上 昇, ICG 亭滞がみられ, HBs 抗体陽性で, IgA 上昇 し, PHA blastogenesis が低下していた，100g GTT で は楛尿病型であった。食道ファイバーで軽度の静脈瘤 (LI，FI， Cb，Eo）がみられたが，胃内視鏡所見でびら ん性胃炎が著明で，吐血の原因と考点られた。

履床経過：[Fig. 1) 過领により倦急感，食欲不振， 覀心, 呕吐, 腹水, 腹痛, 黄疸 吐血, るいそらなどの 症状のいずれかが出現し，著明な肝腫大がみられ，血清 ビリルビン，GOT 及び $\gamma-G T P$ が上㫒し， ICG 停滞が 著明となるが，入院して断酒すると，愁訴は約 1 週間で 消失し，肝機能険查成績は約 1 力月間で改善した。 た，入院期間中に肝尰大が明らかに縮小した。この増悪 と軽快を約 4 年間に 6 回繰り返し, 次第に腹水，食道静 脈瘤が出現した：その間に腹腔鏡検査を 2 回と肝生検を 4 回施行した。

腹腔鏡所見 : 第 1 回目(昭和49年 7 月29日施行)では, 肝賎の尰大が著明で，辺緑は鈍化し，色調は黄色調を加 味し，硬度が増強していた．右葉の表面には，小陥凹が 多数あり, 不平で, 被膜が肥厚し，細血管の增生もみら れた (Fig. 2A). 左葉の表面にす小陥凹が数個あり，や や隆起した平坦な発赤を白斑が取り囲んで斑紋状に見え
た。

第 2 回目（昭和51年 1 月12日施行）では，肝缄は著し く畽大し，辺縁の鈍化む著明で，色調にはやや発赤した 部分があり，硬度はさらに増強していた．右葉の表面に は多数のシンパ小水狍があり，洞漫性の小結節と大きな 陥凹が 2 個あり，肝の形態がゆがんで見えた．被膜が肥 厚し，細血管の増生と蛇行がみられた（Fig. 2B). 左葉 の表面 小小結節状を示し, 被膜が肥厚し, 細血管 の増 生, 蛇行子みられた. 約 1 年半の経過で明らかな結節が 認められるようになった。

肝組織所見：(Fig. 3) 第 1 回目（昭和48年10月12日施 行）では，肝小葉構造は保たれており，肝細胞には脂肪 変性がみられ，肝細胞質内には小硝子体が認められた が，細胞浸潤にはそしく，門脈域の拡大むなかった。小 葉中心部と門脈城を結ぶ幅の狭い線雓があり，肝細胞周 囲の線維す小葉によっては著明に見られた。

第 2 回目（昭和49年 7 月29日施行）では, 肝の小葉改 策が明らかとなり，肝緗胞の変性，壊死がみられたが， 細胞浸潤は少なかった。一部では，小結節性の偽小葉が 形成され，門脈域が桩大して線稚化と胆細管増生がみら れたが，細胞浸潤はこしかった。

第 3 回目（昭和50年 8 月30日施行）では，偽小策形成 がさらに明膫となり, 小結節性で，間質の幅は㢭かっ 


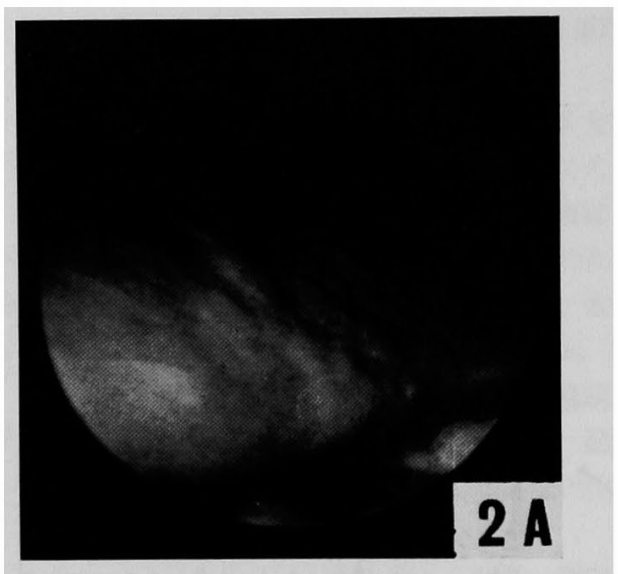

Fig. 2A Laparoscopic view of the right lobe of the liver in case 1 . The liver is yellowish-red in color, round in edge and uneven on the surface.

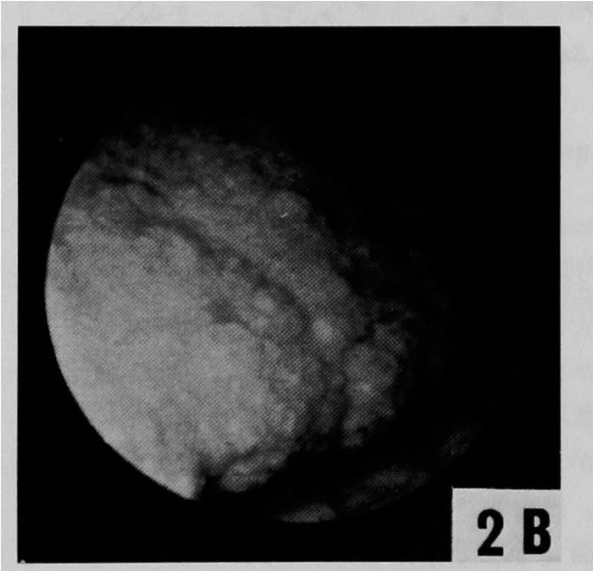

Fig. 2B Laparoscopic view after 18 months of the condition seen in Fig. 2A. The liver edge is more round. Multiple lymphocysts, distorted vessels and small nodules on the liver surface are visualized.

た、偽小葉は唃漫性でなく，小葉满造の保たれた所もあ ったが，肝細胞の変性・壊死およびアルコール硝子体が 認められた，細胞浸潤は乏しかった。

第 4 回目（昭和51年 1 月12日施行）では，偽小葉がほ

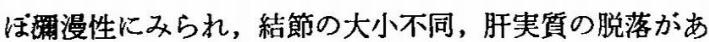
り，門質の幅が広まり，間質内には数個かたまって肝細 胞が残っていた。

以上のように，肝組織所見では軽度の線維化および脂 肪変性がみられた組織と, 肝細胞の変性・壞死が起り, 幅の狭い間質を伴った小結節が次第に形成され，さら

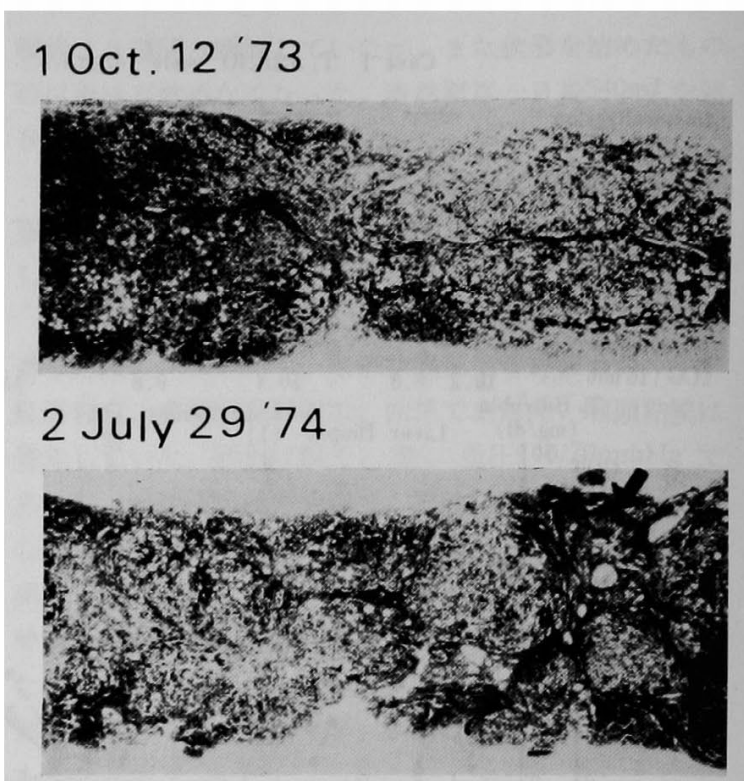

3 Aug. 30 '75

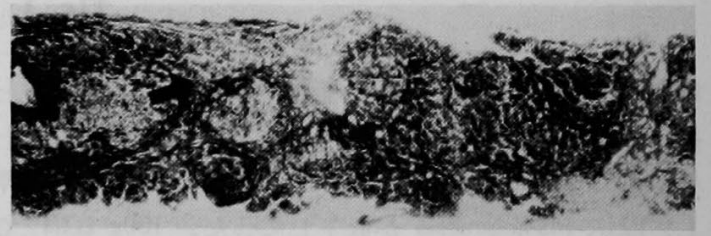

\section{Jan. 12 '76}

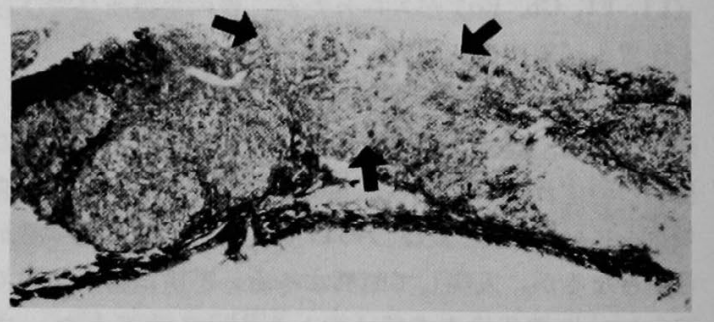

Fig. 3 Changes of liver histology in case 1. (AzanMallory, $\times 20$ ) 1 . Numerous fatty metamorphoses with slight fibrosis. 2. Alcoholic hepatitis with moderate fibrosis. Extension and joining of fibrous septa divide the parenchyma. The portal tract are enlarged by fibrous tissue (arrow). 3. The connective tissue septa become wider than those seen in the 2nd biopsy specimen (arrow). Cellular infiltration is scanty. 4. Postnecrotic cirrhosis with irregular multilobular nodules. Note large area of collapse with ghost lobules (arrows). The progression of alcoholic hepatitis to postnecrotic cirrhosis is observed in this case. 
に肝実質の脱落を生じて, 間質の幅が広まり, 結節の大 小不同む誌められるよらになって, 約 2 年間て壊死後性 肝硬変へ進展した。全経過を通じ門脈域の細胞浸潤が云 しいことも一つの特徽であった。

症例 2 茅○芳○，53歳，湘量技師。

主訴：食欲不振，呕吐，るいそう。

既往歷：昭和 4 年虫垂切除術を受けた。

家族歷：同胞一人が糖尿病である.

领酒歷：昭和15年頃より领酒を覚兄, 昭和24年頃には 清酒概算一日量 $5,400 \mathrm{~m} l$ 位まで連日飲酒し, 昭和 43 年比 肝尰大を始めて指摘され，その後, 節酒を心がけ清酒概 算一日量 $900 \mathrm{~m} l$ 位を連日にわたって副食をほとんど聆取 せす䚿んでいた。間部の辺地に居住し，主として自宅 で拎酒する習慣であったので，約30年間の酒歴記録があ ク，糸くほど大量の倽酒をしていた (Fig. 4).

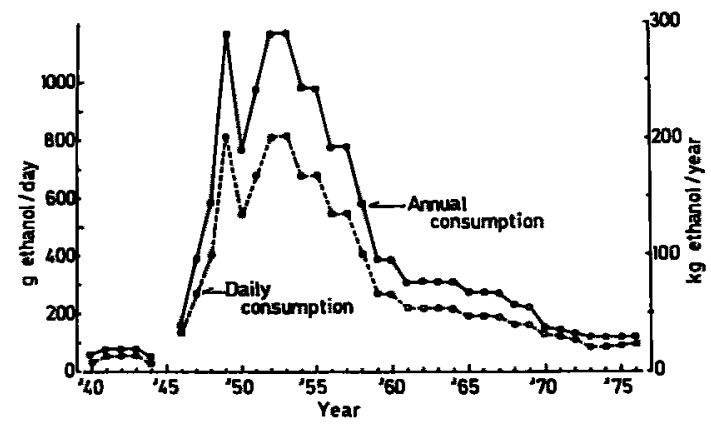

Fig. 4 Amounts of ethanol consumed during drinking life in case 2 .

現病歴：昭和44年頃より早朝菌磨き時に悪心を覚える ようになった。

昭和46年10月頃過欲が続いててのち, 食欲不振, 腹満を 生し，腹水を指摘され，同12月 9 日より昭和 47 年 4 月 9 日まで入院加療を受け，愁訴は消失した，退院後はしば らく断酒していた。

昭和 47 年11月頃より再び飲酒を始め，次第に過飲する ようになり，食欲不振，るいそうをきたし，同12月12日 上り昭和 48 年 2 月 27 日をで入院加療を受け，愁訴は消失 し，体重も增加した，退院後しばらく断酒していたが， 清酒概算一日量 $360 \mathrm{~m} l$ 位から連日领酒を始め, 特に過领 が続くと腹満が起り，食欲不振が增強した。

昭和48年12月10日上り昭和 49 年 3 月 4 日まで入院加療 を受け，愁訴は全くなくなった。同 2 月21日第 1 回目の 肝盲生険を施行した。入院中は断酒していたが，退院後
また领酒を続け，昭和49年 5 月頃より清酒概算一日量 $360 \mathrm{~m} l$ 位拎又，同 10 月頃上り $900 \mathrm{~m} l$ 位飲むようになり， 洔にはI, $800 \mathrm{~m} l$ 位敛むこともあった。

昭和49年10月下旬より食欲不振あり，節酒に上り少し は愁訴が軽快したが，不限となり，全身阭密感出現し， 食欲不振增強し，下䘞が起り，るいそうして入院した。 昭和49年11月28日より昭和50年 2 月 13 日まで入院加療し て，愁訴は消失した．昭和49年12月16日に第 1 回目腹沿 鏡，第 2 回目旰生検を施行した。退院後しばらくして领 酒し始め，次第に飲酒量が增えた。

昭和50年の正月に過领してのち，食欲不振，悪心 呕 吐が出現した。愁訴は次第に増強し，㑷急感強く，鼻出 血あり，食事ができなくなり，飲酒たけを続けるように なった，次第にるいそうし，飲酒む出来なくなって，同 5 月15日入院した，入院後，断酒し，点滴加療により䄪 2 週間で愁訴が消失した。同 5 月 31 日に第 3 回目肝盲生 涘を施行した．同 7 月20日に退院してのち，しばらく断 酒していたが再度领酒を始めて，酒量が次第に增加し， 清酒概算一日量 $900 \mathrm{~m} l$ 位を連日飲み続け，副食はほとん ど提取しなかった。

昭和50年 9 月 8 日頃より吃逆出現 し, 食欲不振, 覀 心，呕吐をきたし，るいそらし，同 9 月18日より昭和51 年 3 月 6 日まで入院加療した。入院後, 断酒し, 点滴加 療に上り愁訴は約 2 週間で消失し，肝機能検査成績は約 2 力月間で改善した。退院後より飲酒し，清酒概算一日 量 $900 \mathrm{~m} l$ 位まで酒量が增え, 食欲不振, 悪心が出現し た.

昭和51年 6 月上旬より吃逆, 食欲不振, 悪心, 呕吐が 增強し，剑酒しても呕吐するよらになり，下䦌，不抿， るいそう（50kg $\rightarrow 43 \mathrm{~kg} ）$ をさし，同 6 月18日より入院 した。同 7 月 5 日に第 2 回目腹船鏡，第 4 回目肝生検を 施行した. 入院後，断酒し，点滴加療により愁訴は消失 した。

現症：（昭和51年 6 月）体格中等，栄着不良，皮庯は 乾燥し, 亜黄疸色で, 星芒状毛細血管怒張, 女性化乳房 が軽度あり，手掌紅斑が鮮やかであった，手指掁戦がみ られた. 珚頭粘膜は発赤していた. 脈拍数は正常で，脈 拍は整であった。血圧150/96mmHg. 眼球結膜鱼黄疸色 て，眼䀫結膜充血していた。葴・肺に異常なかった。 肺肝境界第 6 助骨. 腹部は平坦で敕であり，朋䁍を助马 下約 5 横指径触知し, 辺縁が鈍で, 硬く, 表面平滑で, 圧痛はなかった。脾臓は触知しなかった。滕蓋执よびア キレス腱反射は雨侧とも微弱で，病的反射はなかった。 
Table 2. Case 2 Laboratory findings on admission

\begin{tabular}{|c|c|c|c|c|c|}
\hline \multicolumn{2}{|l|}{ Blood } & \multicolumn{2}{|l|}{ Liver Function } & \multicolumn{2}{|l|}{ Biochemical Test } \\
\hline RBC & $416 \times 10^{4}$ & T. Bilirubin & $3.4 \mathrm{mg} / \mathrm{d} l$ & BUN & $6.2 \mathrm{mg} / \mathrm{d} l$ \\
\hline $\mathrm{Hb}$ & $14.3 \mathrm{~g} / \mathrm{d} l$ & D. Bilirubin & $2.6 \mathrm{mg} / \mathrm{d} l$ & NPN & $13.4 \mathrm{mg} / \mathrm{d} l$ \\
\hline $\mathrm{Cl}$ & 1.07 & $\mathrm{CCF}$ & $(-)$ & Uric acid & $6.7 \mathrm{mg} / \mathrm{d} l$ \\
\hline $\mathbf{H t}$ & $43.0 \%$ & ZTT & 4.7 & $\mathrm{Fe}$ & $139 \mu \mathrm{g} / \mathrm{d} l$ \\
\hline Ret & $40 \%$ & ChEase & $50 u$ & $\mathrm{Cu}$ & $123 \mu \mathrm{g} / \mathrm{d} l$ \\
\hline Thr & $29.5 \times 10^{4}$ & GPT & $99 u$ & CPK & $12 \mathbf{u}$ \\
\hline WBC & 6,400 & GOT & $168 \mathrm{u}$ & $\mathrm{NH}_{3}$ & $53 \mu \mathrm{g} / \mathrm{d} l$ \\
\hline $\begin{array}{l}\text { (St } 4, \text { Seg } 52, \text { E } \\
\text { M } 3, \text { Ly } 41 \text { ) }\end{array}$ & $0, \mathbf{B} 0$ & $\begin{array}{l}\text { ALP } \\
\text { LAP }\end{array}$ & $\begin{array}{l}13.4 \mathbf{K A} \cdot \mathbf{U} \\
253 \mathbf{u}\end{array}$ & $\begin{array}{l}\text { Amylase } \\
\text { Serum Electrolytes }\end{array}$ & $142 \mathrm{u}$ \\
\hline \multirow[t]{2}{*}{ ESR } & $1 \mathrm{~mm} / \mathrm{hr}$ & $\gamma$-GTP & $476 \mathbf{u}$ & $\mathrm{Na}$ & $138 \mathrm{mEq} / \mathbf{L}$ \\
\hline & $5 \mathrm{~mm} / 2 \mathrm{hrs}$ & LDH & $370 \mathbf{u}$ & $\mathbf{K}$ & $3.6 \mathrm{mEq} / \mathrm{L}$ \\
\hline Coagulation Test & & Cholesterol & $90 \mathrm{mg} / \mathrm{d} l$ & $\mathrm{Ca}$ & $4.0 \mathrm{mEq} / \mathrm{L}$ \\
\hline Bleeding time & $1 \mathrm{~min}$ & Triglyceride & $80 \mathrm{mg} / \mathrm{d} l$ & Cl & $108 \mathrm{mEq} / \mathrm{L}$ \\
\hline Coagulation time & $2 \mathrm{~min} 16 \mathrm{sec}$ & MAO & $48 \mathbf{u}$ & Serological Test & \\
\hline Prothrombin time & $11.6 \sec$ & ICG (15min) & $16.0 \%$ & CRP & $2+$ \\
\hline Hepaplastin test & $72 \%$ & Serum Protein & & RA & $(+)$ \\
\hline Thrombotest & $123 \%$ & T. Protein & $6.4 \mathrm{~g} / \mathrm{d} l$ & LE & $(-)$ \\
\hline Fibrinogen & $295 \mathrm{mg} / \mathrm{d} l$ & Alb & $57.3 \%$ & HBs Ag (RIA) & $(-)$ \\
\hline Urinalysis & & $\alpha_{1}-\mathrm{g} 1$ & $4.9 \%$ & HBs Ab (RIA) & $(t)$ \\
\hline Protein & $(-)$ & $\alpha_{2}-\mathrm{gl}$ & $9.8 \%$ & 100g OGTT & \\
\hline Sugar & $(-)$ & $\beta-g l$ & $13.2 \%$ & FBS & $92 \mathrm{mg} / \mathrm{d} l$ \\
\hline Bilirubin & $(-)$ & $\gamma-g l$ & $14.8 \%$ & $1 \mathbf{h r}$ & $194 \mathrm{mg} / \mathrm{d} l$ \\
\hline Urobilinogen & (H) & IgG & $1,250 \mathrm{mg} / \mathrm{d} l$ & $2 \mathrm{hrs}$ & $195 \mathrm{mg} / \mathrm{d} l$ \\
\hline Feces & & IgA & $1,350 \mathrm{mg} / \mathrm{d} l$ & $3 \mathrm{hrs}$ & $132 \mathrm{mg} / \mathrm{d} l$ \\
\hline Occult blood & $(-)$ & $\operatorname{IgM}$ & $205 \mathrm{mg} / \mathrm{d} l$ & Cholecystography & normal \\
\hline Parasite & $(-)$ & $\mathrm{C}_{3}$ & $145 \mathrm{mg} / \mathrm{d} l$ & $\begin{array}{l}\text { P-S test } \\
\text { PHA blastogenesis }\end{array}$ & $\begin{array}{c}\text { hypofunction } \\
27 \%\end{array}$ \\
\hline
\end{tabular}

Case 2 Y. KAYAHARA male $56 \mathrm{yrs}$.

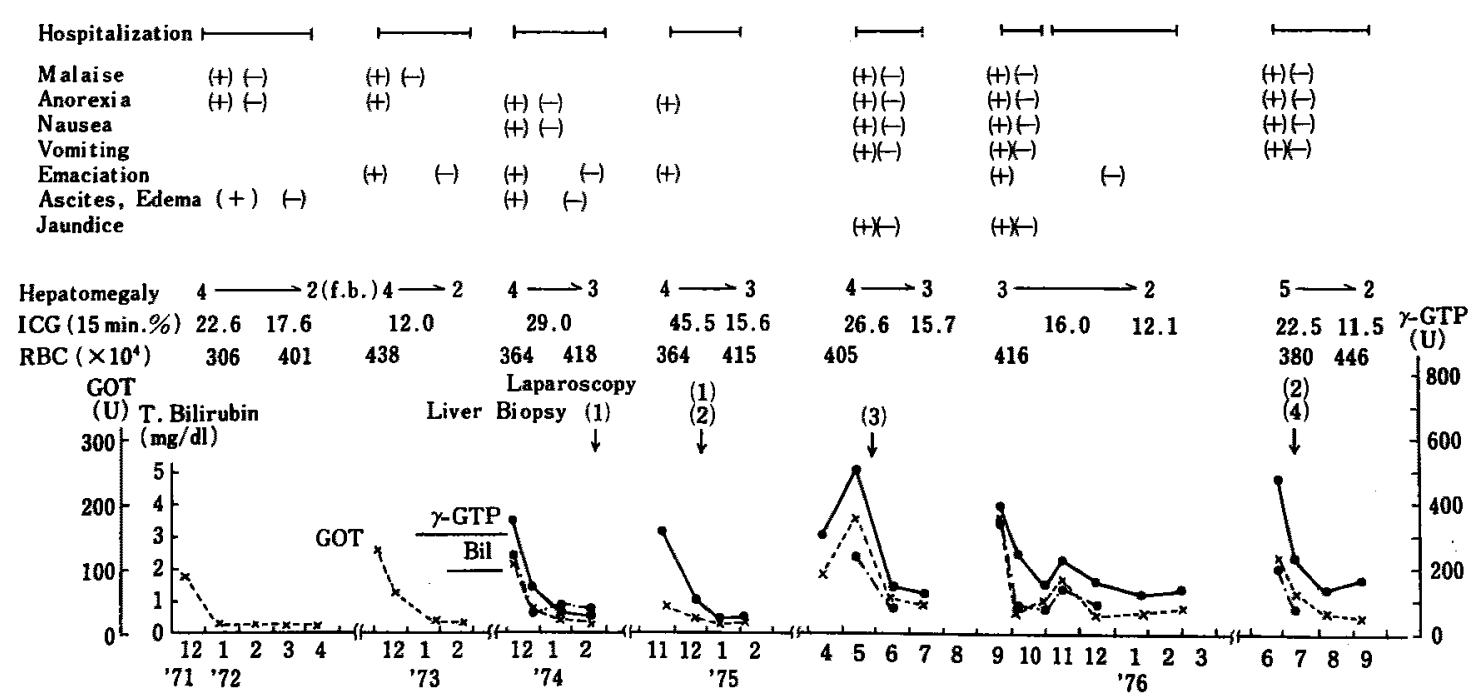

Fig. 5 Clinical course 
浮腫るなかった。

入院時検查成䅡 : (昭和50年 9 月) (Table 2) 血清ビ リルビン上昇，血清トランスアミナーゼ上昇（GOT> GPT), LAP 上昇, $\gamma$-GTP 上昇, MAO 上昇, ICG 停 滞がみられ，血清総コレステロールが低下していた。 IgA が上昇し, HBs 抗体陽性で, PHA blastogenesis が 低下していた。 100gGTT では糖尿型であった。崒機能 低下がみられたが，食道静脈瘤はなかった。

臨床経過：(Fig. 5) 過领により，食欲不振，悪心， 呕吐, 吃逆, 倦总感, 下莉, るいそう, 腹水, 黄应など の症状のいずれかが出現し，著しい肝腫大，血清ビリル

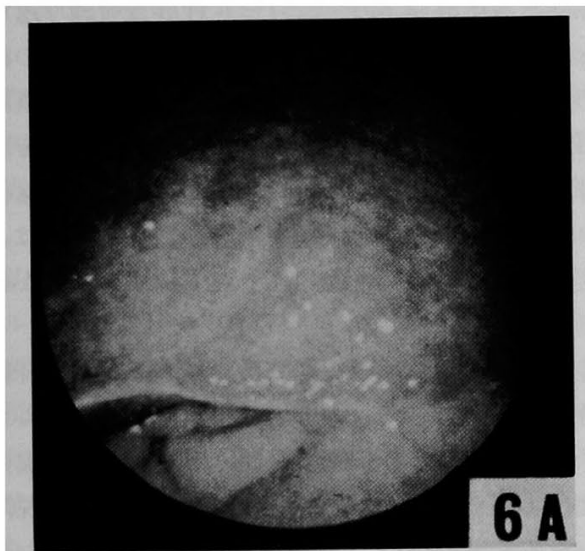

Fig. 6A Laparoscopic view of the left lobe of the liver in case 2. The liver is whitish-red in color and sharp in edge. A large depression and small flattened nodules on the liver surface are visualized.

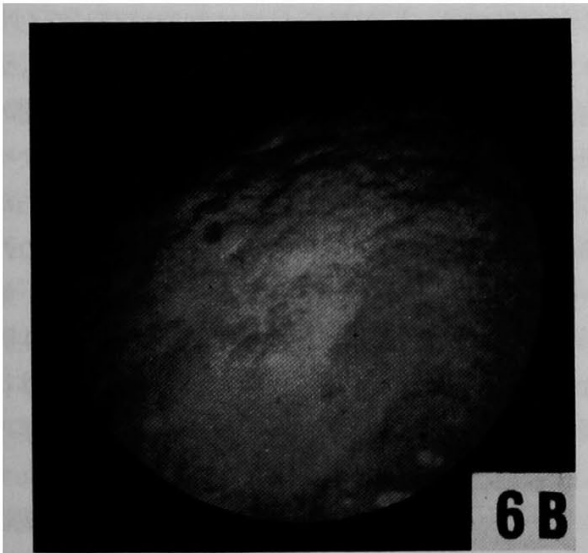

Fig. 6B Laparoscopic view after 18 months of the condition seen in Fig. 6A. Color and surface of the liver are unaltered in contrast to Fig. 6A.

\section{Feb. 21 ' 74}

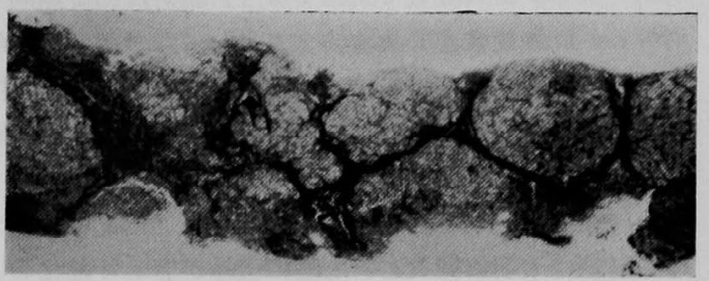

2 Dec. 26 '74

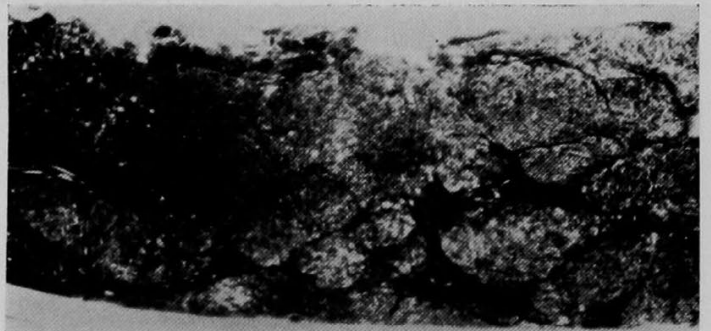

3 May $31^{\prime} 75$

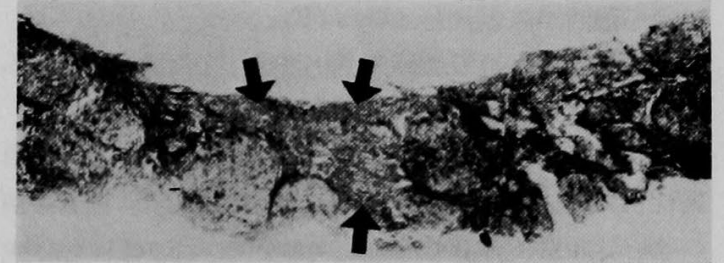

\section{July 5 '76}

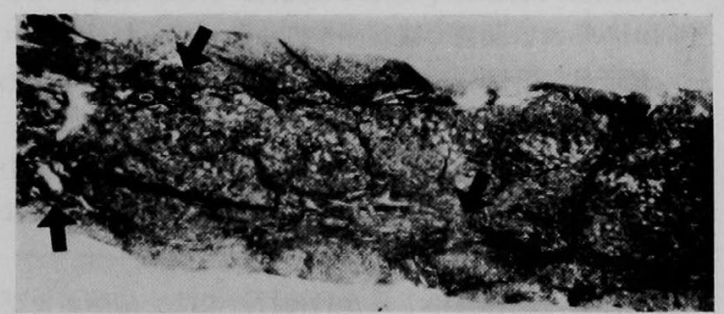

Fig. 7 Changes of liver histology in case 2. (AzanMallory, $\times 20)$ 1. Micronodular (portal) cirrhosis with regular nodules. The fibrous septa are narrow. 2. The connective tissue septa are wider than in the 1st biopsy specimen. 3. Postnecrotic cirrhosis with irregular nodules. Note large area of collapse (arrows). 4. The portal tracts are enlarged by fibrous septa (arrows). The transition of portal cirrhosis to postnecrotic cirrhosis is demonstrated in this case. 
$42: 562$

䏦

ビン，GOT 特よび $\gamma$-GTP 上昇，さらに ICG 停帯が 著明となるが，入院して断酒すると，愁訴は約 2 週間で 消失し, 肝機能検查成績は䄪 2 力月間で改善して, 入院 期間中に肝腫大が緶小した。この增悪と軽快を約 5 年間 に 7 回繰り返し，その間に腹望鏡を 2 回と朋生検を 4 回 施行した。

腹腔鏡所見：第 1 回目（昭和49年 12月 23 日施行）で は，肝臟は著明に腫大し，右葉の辺縁が著しく鈍化し， リンパ小水疮が多数みられ，やや発赤していたが，被膜 の肥厚が著しく, 色調は白色調を帯び, 小陷凹が散在し た. 左葉辺縁には鈍化がみられず，色調は発赤し，表面 に平坦な小結節が密にみられ，小陷凹が散在していたは かに，広い浅い陣凹が辺緣にみられた（Fig. 6A)。

第 2 回目（昭和51年 7 月 5 日施行）では，肝葴は第 1 回目同様に著しく腫大し, 右葉辺緣は鈍化著明で,リン パ小水疱が多数あり, 被膜の肥厚も著しく, 色調は白色 調を帯び，表面には小脽凹が散在し，辺縁に大きい陥凹 がみられ, 平坦な小結節が明らかになった。左葉辺縁は 鈍化し, 平坦な小結節が密にみられ, 小陷凹の散在と広 い浅い陷凹がみられた (Fig. 6B).

約 1 年半の経過では，あまり著明な変化は見られなか ったが，右葉の小結節が明瞭となった。

肝組織所見：(Fig. 7) 第 1 回目（昭和49年 2 月 21 日 施行)では，大きさが结ば均一な小結節性の, 間質の幅 の狭い肝硬変で, portal, micronodular, または regular cirrhosis に分類されらる

第 2 回目（昭和49年12月16日施行）では，結節の大小 不同がみられ, 間質の幅がやや広くなっていた。アルコ

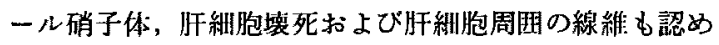
られた。

第 3 回目（昭和50年 5 月 31 日施行）では, 結節の大小 不同がさらに明らかとなり, 間質の幅がますます広くな り，肝実質の脱落が認められた。

第 4 回目（昭和51年 7 月 5 日施行）では, 絬節おょび 間質の状態は第 3 回目とあまり変化がみられなかった が, 肝細胞の脂肪変珄, 壊死およびアルコール硝子体お よび肝細胞周囲の線維が明らかであった。

肝組織所見では, portal (or micronodular, regular) cirrhosis は次第に結節が大小不同となり, 間質の幅が広 くなり, 肝実質の脱落がみられて，約 1 年間で postnecrotic (or irregular) cirrhosis よなった.

考察

両症例とも大量に長期閆にわって飲酒が可能であった
18 巻 8 号 (1977)

がひとたび肝障害が発症したのちは, 過飲による增覀 と，断酒による軽快を綝り返した。増悪期には種々の 愁訴が出現し, 䀒機能異常を伴い, 肝組織所見ではアル コール性肝炎であった．軽快すると種々の愁訴が消失 し，肝機能異常が改善し，肝組織所見では種々の程度の 線維化を伴っていたが肝細胞壞死，アルコール硝子体は 改善した。このことは，アルコール摄取のために 栄盖 不良も重なって，肝機能が悪化し，その原因が除かれる と改善し，薬凧性肝炎診断のさいに行なわれる Challenge のよ5に, 両症例の肝障害がアルコール摂取によっ て発生したことを明らかにしたものといえよ5. Ström むアルコール恸取によりアルコール性肝炎を繰り返す一 症例を報告している。臨床症状発現までに長期間の飲酒 歴があり，この期間肝は腫大するが，アルコール撕取に 適応可能であり，次第に適応できなくなった原因を臨床 的には明らかにできなかった。しかし，肝障害発見後の アルコール摂取による急性增悪と肝硬変への進展は，こ れら症例の経時的な訮生検の繰り返しにより明らかにさ れた。

急性增悪期はアルコール性肝炎に相当し，その剈組織 像の特徽の一つとして, 主として小葉中心性のアルュー ル硝子体出現を伴う肝細胞の変性・壊死があり，壊死の 程度はさまさきで巣状からかなり広範な肝実質の脱落ま でみられることについては，我々すすでに報告した通り である゙!。

肝硬変への進展については, 症例 1 のように脂肪変性 と軽度の線維化の状態から約 2 年間で明らかな肝硬变か 形成され，その進展がかなり速やかに起ることが示され た.この症例では，訮組織所見では細胞漫潤が云しく， アルコールの肝実質細胸への值接的な影響が加わって， 肝細胞壊死が綝り返された結果と示唆される、飲酒のた め食慨摄取が不充分で，栄養不良についても考慮すべき であるが，この栄湌不良は慢性フルュール症のために連 日飲酒した結果生した 2 次的現象と考古られ，そのため にアルコールによる肝障害が助長されたとしても，栄養 因子が一次的役割を果したという確証がない，慢性訮炎 の場合でも，実質壊死を伴う型では肝硬変への移行が 短期間でみられるが，フルコール性肝硬变の進展のさ いにる肝細胞珓死亡線維化の進展との関連が示されてい、 る ${ }^{109}$. しかし，本例では，慢性肝炎に比べて門脈城の炎 症細胞浸潤が少ないなどの違いがあり，慢性肝炎と同じ ような機序で肝細胞罣死が起ったとはいい難い。

さらに，病因に関する愉討では，両淀例之も発症時に 
HBs 抗体が陽性で，HBs 抗原感梁の機会があったこと は確実であり, 肝硬変の進展に何らかの影響を及ぼして いたとも考光られるが，一般炕多飲者では HBs 抗体陽 性率は高值といわれるので"”，流行地など地域的な影響 が考慮されるものの, 単に HBs 抗原に感染する機会 が多かったことを意味するにすぎず，肝硬変の進展に HBs 抗原が直接的には影響を及ぽしていないと思われ る.

症例 2 では，門脈性あるいは小結節性肝硬変が光顕的 には壊死後性の特徽を示寸肝硬变へと進展 した，Rubin $ら^{(2)}$ は，フルコール中毒者の 肝便変の剖検材料をもと K, 門脈性肝硬变から壊死啳性肝硬変への移行例を検討 して、フルコール性肝硬変が壊死後性の型をとることを 示した. そのさいウイルス肝炎後に生じるような粗大結 節性でなく, 光顕的に壊死後性の特徽をむつ肝硬変であ ったと述べている．本例も肝表面の所見では，結節が小 さく，光影的レベルで次第に壊死後性の型を示すことが 経時的な肝生検の結果から明らかとされた。

フルコール性肝炎から肝硬変への移行が断酒を続け充 分に栄養を摄取していても認められることがあり, 自己 免疫現象が慢性化の過程に関与しているのではないかと す考えられている 值を示していたが, Zinneman ${ }^{14)}$ はフルコール性肝硬変 にみられる血清中 IgA の高值はアルコール硝子体と関 連があり，巣光抗体法による観察では，IgAはアルュー ル硝子体と結合しアアルュールの組織傷害に関与する自 己抗体ではないかと想定している．PHA 刺激に対する 末梢リンパ球反応低下るみられたが，この成績はフルコ 一ル性肝疾患では，アルコール自体や各種の栄養因子欠 乏の影響を受けてる低下するといわれで，肝障害の原因 か結果か明らかでない. 近年, Leevy $ら^{4,13,16)}$ の、フル コールによって傷害された肝は新しい抗原として作用 し，肝障害を持続させ，フルュール硝子体は Tおよび B 細胞を刺激する能力を有し， $\mathrm{T}$ 細胞の刺激により線維化 因子が遊離され，この因子がフルコールの毒性と共に線 維化に重要な役割を果しているのではないかとの報告が ある.我々も，今後このような方面からの検討を行なら 積りであるが，上記 2 症例については，一時的な断酒を 行なったが, 永久的な断酒には失敗した症例であり，病 状の進展の機序は前述のようにアルコール性肝炎の絽り 返しによるものと考点るのが妥当であると思われる。

$$
\text { 結 語 }
$$

長期間にわたる大酒家が過领を契機として，肝機能が
悪化し，断酒により柽快しこの增覀と軽快を繰り返し つつ短期間で肝硬変が進展し, 光湿的に潒死後性の特徽 を呈す過程を示し，旰硬变の進展に及ぼすフルュール性 肝炎の意義についても考察した。

\section{文献}

1) Galambos, J.T.: Natural history of alcoholic hepatitis. III. Histological changes. Gastroenterology, 63: 1026, 1972.

2) Galambos, J.T.: Alcoholic hepatitis: Its therapy and prognosis. In Progress in Liver Diseases, Vol. IV, ed. by Popper, H. \& Schaffner, F., Grune \& Stratton, New York, $1972, \mathrm{p} 567$.

3) Lieber, C.S.: Alcohol and malnutrition in the pathogenesis of liver disease. JAMA, 233: 1077, 1975.

4) Leevy, C.M., Chen, T. et al.: Liver diseases of alcoholic: Role of immunologic abnormalities in pathogenesis, recognition and treatment. In Progress in Liver Diseases, Vol. V, ed. by Popper, H. \& Schaffner, F., Grune \& Stratton, New York, 1976, p516.

5) Galambos, J.T.: Classification of cirrhosis. Amer. J. Dig. Dis., 64: 437, 1975.

6) Rubin, E. \& Popper, H.: The evolution of human cirrhosis deduced from observations in experimental animals. Medicine, 46: 163, 1967.

7) Ström, J.: Acute alcoholic hepatitis. A case with repeated attacks. Acta Med. Scand., 177: $371,1965$.

8) 竹林治朗, 山田信行他 : フルコール性肝炎の臨 床・病理的検討. 日消会誌, $74: 449,1977$.

9）滰野辰郎, 高橋示人他：犬山分類における慢性 幵炎の問題点, 慢性肝炎一その後, 第 6 回犬山 シンポシ்ム記録. 中外医学社, 東京, 1975 , p. 3 .

10) Galambos, T.: The course of alcoholic hepatitis. In Alcoholic Liver Pathology, ed. by Khanna, J.M., Israel, Y. \& Kalant, H., Addict. Res. Found. Books, Tronto, 1975, p97.

11）内藤紿彦：ウイルス朋炎流行地に打ける HB 抗原陽性者の疫学 扩よび 臨床的研究. 第 2 編 
追跡調查と臨床的検討. 肝茂, $17: 288,1976$.

12) Rubin, E., Krus, S. et al.: Pathogenesis of postnecrotic cirrhosis in alcoholics. Arch. Path., 73: 288, 1962.

13) Zetterman, R.K. \& Leevy, C.M.: Immunologic reactivity and alcoholic liver disease. Bull. N. Y. Acad. Med., 51 : 533, 1975.

14) Zinneman, H.H.: Autoimmune phenomena in alcoholic cirrhosis. Amer. J. Dig. Dis., 20 :
$337,1975$.

15) Sorrell, M.F. \& Leevy, C.M.: Lymphocyte transformation and alcoholic liver injury. Gastroenterology, 63: 1020, 1972.

16) Leevy, C.M., Zetterman, R.K. et al.: The lymphocyte and liver disease of the alcoholic. In Alcoholic Liver Pathology. ed. by Khanna, J.M., Israel, Y. \& Kalant, H., Addict. Res. Found. Books, Tronto, 1975, p157.

\title{
Alcoholic cirrhosis with repated attacks of hepatitis
}

\author{
Jiro Takebayashi, Sadaka Iwahara, Kenji Jinno, Nobuyuki Yamada, Nobuya \\ Sasakr, Akiyoshi Dan, Harumi Yamamoto*, Kazufumi Hirata, Hiroyasu \\ Hirakawa, Yoshihiro Shimada and Hideo Nagashima**
}

The patients in this study were 43 and 53 year-old men. They were constant drinkers and consumed over $150 \mathrm{~g}$ of ethanol per day for a period of 20 to 30 years before initial hospitalization. They had alcoholic hepatitis, with and without cirrhosis. Alcoholic hepatitis subsided after 2 months of admission. After hospitalization, the patient who had abstained returned to their previous drinking habits. They had repeated attacks of hepatitis on 6 to 7 occasions within a space of 4 to 5 years. Laparoscopic examination and liver biopsy were undertaken repeatedly during the 4 to 5 year follow-up period. In these observations, cirrhosis developed in one patient with alcoholic hepatitis within 2 years. In the other patients, the transition of portal cirrhosis to postnecrotic cirrhosis occurred within 1 year.

In this report, it is revealed that alcoholic hepatitis plays a prominent role in the progression of cirrhosis. 